\title{
EDUVELOP
}

Journal of English Education and Development

Volume 1, No. 2, March 2018

ISSN 2597-713X (print)

ISSN 2597-7148 (online)

\section{A Descriptive Case Study of Using Line Application for Learning Writing \\ Paskalina Widiastuti Ratnaningsih}

English Education Department, Musi Charitas Catholic University

E-mail: paskalina.widiastuti.r@gmail.com

\begin{abstract}
Writing as part of English skills is highly concerned in the present days. The development of technology influences the use of media for teaching-learning activities. This paper aims at discovering students' learning in English writing by using Line application as the media for learning. As one of the applications in the smartphone, Line application can be used in the teaching-learning activities. A task-based instruction is applied in the study. The method of study is case-study. The data were gathered with observation, interview, and document review. Holistic analysis was conducted after getting the data. The research result is writtten in descriptive. The description is divided into major themes. The themes are mainly in the scope of the use of technology for writing.
\end{abstract}

Keywords: Case study, line application, writing, task-based instruction

\section{Introduction}

Teaching and learning activities are influenced with technology exposure in the present days. Input of learning is from different sources. Input is needed before the process of writing. Lesson in the classroom and information in the internet can be used as the source for writing. Internet is used for getting broader knowledge and

Vol. 1 No. 2 March 2018 information. Online learning with internet is used in the teaching-learning activities (Dudeney and Hockly, 2007, p.152). Technology enters the classroom nowadays. Writing needs process in forming the sentences and paragraphs. After having the input, the students process the information to be written. Input is used to get the output (Harmer, 2001, p. 250). The process starts from getting the idea, writing the sentence, 
setting the paragraph, and write in the media. The media for writing task can use technology or without technology. The media that is usually used is paper for writing. However, technology has a role in the the learning process. Applications in the smartphone develop faster nowadays. Hence, technology can be used for writing. Line application as one of the applications that people mostly use. Line application can be used for sending messages, calling, and writing notes. With broader use, Line application is used as the media for writing. The students can also use Line application for their personal use. Levy in Donaldson and Haggstrom (2006: 7) states that " whereas with tasks the focus is on task design, with communications technologies the focus should be on selecting the right technology for the task." Hence, Line application is appropriate to be used as the media for writing. Since writing and technology are important in the present days, this study focuses on discovering students' learning by using Line application as the media for writing. This study has two limitations. The first is the use of Line application. Line application is limited to the use of group notes since it is the feature that can be used for writing. The second is the scope of study. This study is limited in South Sumatera area that is focused on Musi Charitas Catholic University. Hence, this study is focused to answer this research question: How is Line application used in learning writing? The research goal is to find out the use of Line application in the present era for learning writing.

\section{A. Case Study}

Case study focuses on specific case to be discover. Creswell (2007: 73) states that "case study research involves the study of an issue explored through one or more cases within a bounded system". In-depth description is needed after analyzing the data (Creswell, 2007: 78). The description must provide not only broader narrative, but also it provides deeper narrative of the case. The description is divided into several theme based on the case (Creswell, 2007: 79). The themes are determined based on the data analysis. Stake in Cresswell (2007, 74-75) states five steps to conduct case study. The first is research problem. The research problem must be determined exactly based on the case to be solved. The second is identifying the case. The case can be single case or multiple cases. The case can also be in single site or multiple sites. The third is data collection. The data collection must be gathered broadly with several instruments in order to get important data findings. The fourth is holistic analysis. The data is analyzed according to the chronology of case, event, and time. It also focuses on the context of study. Overall analysis is needed in the case study. The fifth is meaning of the study. After having the description, the researcher points out the significant meaning based on the case that is being studied.

Vol. 1 No. 2 March 2018
EDUVELOP

Journal of English Education and Development Universitas Sulawesi Barat 


\section{B. Teaching Writing}

Brown (2007, 402-404) suggests six principles in teaching writing. From those 6 principles, there are three principles that are considered important and related to this research. The first is process and product. Teaching writing is not only about producing writing texts, it is also about having the process. The process itself includes the process of thinking. The second is reading and writing. Before writing, the students need to read as the input. Hence, the students must balance reading and writing activities. The third is prewriting, drafting, and revising. In the prewriting step, the students try to brainstorm several inputs. In drafting step, the students make their writing version before revising. In revising step, the students revise their writing work. Reid in Carter and Nunan (2001: 32) states five techniques in second language writing. The first is need analysis of the curriculum. The second is group work of writing. The third is integration of language skills. The fourth is understanding learning style and strategy. The fifth is the use of authentic materials. Murray and Hughes (2008: 46-57) state three major parts in writing. The first is introduction. Thesis statement needs to be written in the beginning as the focus of writing. Context of writing is also needed to be stated. The second is writing organization. Topic sentences, and supporting sentences must be related one another. The third is conclusion. The summary must reflect the point of the writing. (Syamsiah Syamsiah 2017) The purpose of teaching writing is the students are expected to convey the accurately, fluently, and appropriately messages in short monologues/essays in daily life context and get access to popular sciences (standard of competence). Courses objectives students will be able to write a text well and correct. The stories is one of the technique will interest the students to learn more enjoyable and pleasant in the classroom.

\section{Task-Based Instruction}

Task-based instruction deals with task done by the students. Freeman (2000: 144) states that "a task-based approach aims to provide learners with a natural context for language use". Hence, the students need to acknowledge the context of writing. Freeman (2000: 146-148) states nine principles of conducting task-based instruction. The first is clear purpose and outcome. The second is having pre-tasks. The third is logical thinking of the activity. The fourth is adjustment of the task. The fifth is comprehending the use of language. The sixth is stating again the task. The seventh is information of the task. The eighth is feedback of the task. The ninth is meaningful interaction.

In doing the tasks, the students have their own learning styles. Reid in Egbert and Smith (1999) states that learning style is "an individual's natural, habitual, and preferred way(s) of absorbing, processing, and retaining new information and skills". Hence, each student has different learning style in doing their task. Egbert and Smith (1999: 292-296) state two learning styles. The first is cultural learning style. The learning style is based on the culture that the students involve in. The second is individual learning style. This learning style is divided into cognitive dimension, 
affective dimension, perceptual dimension, and psychological dimension.

\section{Line Application}

Line application is one of the applications in the smartphone. Line application has three major features, namely calling, message, and group note. It is connected with internet (Russel, 2016). Calling and message are the features used for personal need. On the other hand, group notes can be used as the media for learning. When the students make notes, they write by typing in their smartphone. Hence, group note is used for learning writing. Group notes means the students can make a class group where the students can write and also see their friends' writing works in the group.

\section{Method}

This study is a case study research. Creswell (2007: 73) states that "case study research is a qualitative approach in which the investigator explores a bounded system (a case) or multiple bounded systems (cases) over time, through detailed, in-depth data collection, involving multiple sources of information." The study focuses on deeper meaning from the study. Instruments needed in this study are taken from several parts. Creswell (2007: 75) states that "The data collection in case study research is typically extensive, drawing on multiple sources of information, such as observations, interviews, documents, and audiovisual materials". In this study, two classes use Line application for writing. The number of students that use

Vol. 1 No. 2 March 2018
Line application is 39 students. The students write thirteen times in one semester. The topics related to economy, namely budgeting, living independently, investment, saving, credit, consumer privacy, and consumer awareness. The researcher conducts the observation in one semester in the classroom and when the students write in Line application. The documents are from students' writing in Line application. Then, out of 39 students, the researcher chooses four participants to be interviewed.

\section{Discussion}

The result and discussion are divided into four major themes based on the data analysis from the observation, document, and interview. The themes are mobility, internal motivation, typing process, and writing improvement.

\section{A. Mobility}

Four participants in the classroom state that the use of Line application makes them more flexible. They can do their tasks anywhere and anytime. They write their writing assignments outside the classroom. They do the tasks at home or when they are outside home. They also can do the tasks in the morning, afternoon, or evening. It helps them much when they must write their writing tasks. It means that Line application is appropriate to be used as part of the techonology in writing task. It supports Levy in Donaldson and Haggstrom (2006: 7) to choose the right technology in the teaching-learning activity. 


\section{B. Internal motivation}

The participants have internal motivation to write in Line application. They are motivated to write in Line application every week. They are also happy when they write in Line application for several reasons. The first is simple and up-to-date. Line application is an up-to-date application since it is used by many people. It is also easy to be used. The students just make a group in Line application and then they write in group note each week. They also can see other friends' writing tasks and it makes them be able to learn from their friends' writing. They can also use Line application for calling and message other than doing their writing tasks. It means that Line application has multiple function and it is appropriate to be used. It is as stated by Russel (2016) that Line application can be used for group notes, calling, and message. The second is internet connection. When the students do their writing in Line application, they are connected with internet. Hence, they can also search in the internet when they need input such as information needed in the writing. It supports the use of input by (Harmer, 2001, p. 250). The students can open online dictionary when they do not know several words. The third is information in Line application. When the students post their writing in Line application, there is information of date and time of posting their writing. It helps them to be on time to

Vol. 1 No. 2 March 2018 submit their writing each week. The fourth is unexpensive. The students just need internet connection in which they also buy internet quota each month for personal need other than submitting their writing tasks.

\section{Typing Process}

Typing process is the development that the students get. When the students write their writing tasks in Line application, they submit their tasks by typing in Line application. Typing is not the students' habit when they do their tasks. They usually write in the paper. Typing in Line application itself has challenges. The students need to be careful when they type since the keyboard pad in the smartphone is small in which they need a good skill when they want to write rather longer writing. Sometimes, they can make mistakes when typing in the smartphone, and then they use backspace to correct their writing. If it is typed uncarefully, the students can also submit unfinished writing when they unintentionally press wrong button. Hence, the participants mostly type their writing in the handphone note firstly so that if they make mistake in typing, they still can revise it and it is also not directly submitted. After finishing their typing of writing in handphone note, they copy and paste their writing result in group note in Line application. It means that they need two stages of typing in the smartphone. Hence, the students have development to have typing habit in the handphone when they do their tasks since they usually have writing habit in the paper to do the task. It means that the students are influenced by both 
cultural learning and individual learning style as stated by Egbert and Smith (1999: 292-296). The cultural learning style is in the sense of having habit to write in paper. Then, they try to have new habit by typing the task in Line application. Individual learning style is in cognitive dimension where the students use their cognitive in writing. Good typing habit in handphone is needed in this era since most activities are conducted with handphone.

\section{Writing Improvement}

The students have improvement in their writing since they write thirteen times in one semester. The students try to improve their writing in each week. They reflect from their previous writing and also learn from their friends' writing. The students can look at other students' writing in group note in Line application. It is as stated by Brown (2007, 402-404) that the students have process and product in writing. The improvement is three types. The first is the use of vocabulary. The students use various vocabularies generally and in economics terms. Since they write each week, they get more exposure of vocabulary. Economics terms that they learn also improve. It is as stated by Freeman (2000: 146-148) related to the use of language in doing the task. The second is writing organization. The students have awareness on how to write their ideas in paragraph and how to connect ideas among paragraph. It is as stated by Murray and Hughes (2008: 46-57) that writing needs to have good organization in the paragraph. The third is length of paragraph. The students try to make longer paragraph every time they write in which they need to think hard of the content of writing.

\section{Conclusion}

In this study, the use of Line application give four meanings to the students based on the themes. The first is mobility. The students have flexibility in using Line application when they submit their writing tasks. The second is internal motivation. The students are motivated to use Line application for writing. The third is typing process. The students have stages in typing their writing in Line application. The fourth is writing improvement. The students improve their writing in vocabulary, writing organization, and length of the paragraph. It can be concluded that the use of Line application is beneficial to be used for writing tasks.

\section{References}

Carter, R. \& Nunan, D. (2001). The Cambridge Guide to Teaching English to Speakers of Other Languages. Cambridge: Cambridge University Press

Creswell, J.W. (2007). Qualitative Inquiry and Research Design: Choosing Among Five Approaches. California: Sage Publications, Inc.

Donaldson, R.P. \& Haggstrom. M.A. (2006). Changing Language Education Through CALL. New York: Routledge. 
Dudeney, G. \& Hockly, N. (2007). How to Teach English with Technology.

Essex: Pearson Education Limited.

Egbert, J. \& Smith, E.H. (1999). CALL Environments: Research, Practice, and Critical Issues. Virginia: Teachers of English to Speakers of Other Languages, Inc.

Freeman, D.L. (2000). Techniques and Principles in Language Teaching. Oxford: Oxford University Press.

Harner, J. (2001). The Practice of English Language Teaching. Essex: Pearson Education Limited.

Murray, N. \& Hughes, G. (2008). Writing Up Your University Assignments and Research Projects: A Practical Handbook. New York: McGraw-Hill Education.

Russel, J. (2016). Understanding Line, the chat app behind 2016's largest techIPO. Retrieved from https://techcrunch.com/2016/07/1 4/understanding-line-the-chatapp-behind-2016s-largest-techipo/ on January 15, 2018

Syamsiah Syamsiah. 2017. "The Effect of the Use of Stories in Improving the Writing Ability of the Second Year Students of Mandrasah Tsanawiyah Negeri Mangempang Barru." EDUVELOP (Journal of English Education and Development) 1 (1):57-66.

ojs.unsulbar.ac.id/index.php/eduvelop. 